\title{
Emma and the Death's Head Hawkmoth (Ema a Smrtihlav)
}

Author: Peter Krištúfek

First Published: 2014

\begin{abstract}
About the Author: Peter Krištúfek (1973-2018) was a Slovak writer and filmmaker. He graduated with a degree in Film and Television Direction from the Academy of Performing Arts in Bratislava. He worked as a moderator in various radio stations. Krištúfek filmed around 20 documentaries as well as some feature films based on his own screenplays. For instance, his documentary Join Us When You're a Rebel (2012, Pridaj sa k nám, ked'si rebel) depicted the extremist movement in Slovakia. In his works, he often used dramatic storylines and fantastic motifs. He died in a bus accident near Banská Bystrica in 2018.
\end{abstract}

Further Important Publications: Dom hluchého (2012, House of the Deaf Man; novel); Atlas zabúdania (2013, The Guide Book of Forgetting; historical documents from 1914 to 2013); Nepresné miesto, Volným okom, Hviezda vystrihnutého záberu (2018, An Inaccurate Place, With a Free Eye, The Star of the Scene That Was Edited Out; two collections of short stories and one novella).

\section{Content and Interpretation}

The novella is divided into four parts. It begins and ends with a short background story in 1961. The main character, Simon (Šimon), 29 years old, spends his holiday on the Black Sea coast in Bulgaria with his wife and two children. He can't swim and this is the first time he sees the sea.

The main narrative is set in Slovakia between 1937 and 1945. In 1937 Simon is five years old and lives with his parents and his younger brother Leo in Bratislava. His father is a Czech architect who designs dams and his mother is a Slovakian Jew who makes women's clothes sewing fashion costumes and women's dresses. Both brothers visit a synagogue with their mother on Saturdays and a Catholic church with their father on Sundays.

After the foundation of the Slovak clerofascist republic and the outbreak of World War II, the family's situation becomes complicated. The father must leave to the Czech lands and the mother and children are threatened by persecution for being Jews. In 1942, when the transport is coming, Leo and his mother flee to Central Slovakia while Simon is hidden in the village of Biskupice near Bratislava, in the barn of his mother's friend, the old néni (aunt) Marika. Simon spends all his time alone with smelly pigs and goats. In the winter, he suffers from the cold, his toes get frostbitten. He reads some magazines and watches a death's head hawkmoth in the barn. Simon invents a story in his imagination where a beautiful woman named Emma is lying in a deck chair on the beach and is threatened by a German General wearing a picture of a 
death's head hawkmoth on his cap. He calls him General Death's Head Hawkmoth. The General imprisons Emma in his house but Simon sets her free and they run away together.

After the war, Simon's father comes for him and they return to their flat in Bratislava. All the family members survive. His mother wants to thank Marika for Simon's rescue, but Marika has disappeared without a trace. At the end, the novella returns to the background story. On the beach, Simon sees his wife in a yellow swimsuit sitting under an umbrella. She looks similar to Emma.

The story is narrated in the third person, nevertheless from the point of view of the main character Simon. His naive, unburdened mind draws a sharp contrast to his dangerous situation. That is why he escapes to daydreams. Emma on the one hand is a figure that he saw in a magazine advertising sunscreen. She embodies peace and love. On the other hand, General Death's Head Hawkmoth incorporates danger and evil. Simon saw this moth in his father's butterfly collection and it was also on the uniforms of the Slovak fascists.

\section{Main Topics and Problems}

Emma and the Death's Head Hawkmoth was Krištúfek's third work of prose inspired by Slovak history, it followed House of the Deaf Man (2012) as well as The Guide Book of Forgetting (2013). The author was interested in Slovak historical events in the 20th century that indirectly project into the present. According to Krištúfek, general models of human behaviour could be found there.

The perspective of a child is very often present in Holocaust literature. Inter alia, it is used in Arnošt Lustig's $\rightarrow$ Diamonds of the Night, Henryk Grynberg's $\rightarrow$ The Jewish War, Josef Škvorecký's $\rightarrow$ The Menorah, Ota Pavel's $\rightarrow$ The Death of the Beautiful Deer, Vincent Šikula's $\rightarrow$ The Lilies of Erika, Wilhelm Dichter's $\rightarrow$ God's Horse and in many films. Similar to all these works, Peter Krištúfek exploits childish naivety, simpleheartedness and imagination. Unlike other literary works, the prematuraly growing up of Jewish children in ghettos or camps (for instance Wojdowski's $\rightarrow$ Bread for the Departed or Ota Pavel's $\rightarrow$ The Death of the Beautiful Deer) is not presented here.

The second aspect of the narration is its sophistication and refinement. The author uses a complex network of motifs (the death's head hawkmoth), their variations (Emma in Simon's imagination in the barn, Simon's real wife on the Bulgarian beach). Some important plot connections are intentionally omitted and readers have to guess them. Fast changes of situations and black humour are reminiscent of an action movie. This art of narration is similar to Pavel Rankov and his novel $\rightarrow$ It Happened on the First September (or Whenever) or Igor Ostachowicz's $\rightarrow$ Night of the Living Jews.

The background story, taking place in Bulgaria more than 15 years after the war, manifests Simon's trauma and his physical disability (frostbitten toes). As at the time of his hiding during the war, he is still feeling threatened and sees the dream figure of Emma in his wife. 


\section{Cited Work}

Krištúfek, P. (2014). Ema a Smrtihlav. Bratislava: Artforum.

\section{Further References}

Csiba, K. (2014). História v próze Petra Krištúfka (historický príbeh v beletrii a v historiografii). Romboid, 49(5-6), pp. 69-72. Guziar, M. (2016). Obrázok holokaustu. iLiteratura.cz, 14.01. Available at: www.iliteratura.cz/Clanek/35881/kristufek-peter-ema-asmrtihlav [Accessed: 18.08.2019]. Krištofová, S. (2016). Ema a smrtihlav. iLiteratura. $c z, 14.01$. Available at: http://www.iliteratura.cz/Clanek/35891/kristufek-peter-ema-asmrtihlav-2 [Accessed: 18.08.2019]. Mašlejová, D. (2015). Ema a Smrtihlav - Peter Krištúfek. Knižná revue, 25(3). Available at: www.litcentrum.sk/recenzia/ema-smrtihlavpeter-kristufek [Accessed: 08.08.2019]. Nagy, D. (2018). Malá slovná daguerotypia. O Petrovi Krištúfkovi. Fraktál, 1(2), pp. 141-143. Součková, M. (2014). Zneužitá história. In: A. Gemra, A. Mazurkiewicz, eds., Literatura i kultura popularna. Badania i metody. Wrocław: Pracownia Literatury i Kultury Popularnej oraz Nowych Mediów, pp. 153163.

$\mathrm{JH}$ 